\title{
Monthly balance and water discharge of an inter-tropical glacier: Zongo Glacier, Cordillera Real, Bolivia, $16^{\circ} \mathrm{S}$
}

\author{
Bernard Francou, Pierre Ribstein, \\ L'Institut Français de Recherche Scientifique pour le Développement en Coopération, CP 9214, La Paz, Bolivia \\ RONALD SARAVIA, \\ Compañia Boliviana de Energia Eléctrica, CP 353, La Paz, Bolivia \\ ERIC TIRIAU \\ L'Institut Français de Recherche Scientifique pour le Développement en Coopération, CP 9214, La Paz, Bolivia
}

\begin{abstract}
Measurements of mass balance were performed every month on Zongo Glacier, Bolivia. Simultaneously, water-discharge, temperature and precipitation data were obtained. The first year of the survey, 1991-92, was marked by an ENSO (El Niño-Southern Oscillation) event with high temperature and low precipitation, whilst the following year, 1992 93, was normal. Results point to the early and late wet season (October-December and March-May) as playing a critical role in the determination of the annual mass balance. The wet season is the warmest period of the year and consequently the duration of the wet season is a highly relevant variable in determining mass balance. Both glaciological and hydrological methods for the determination of the mass balance provide similar results. Our study confirms that ENSO events have a major influence on the rapid glacier retreat currently affecting this part of the Andes.
\end{abstract}

\section{INTRODUCTION}

Very few studies have been performed on the mass balance of glaciers situated between the tropics. The only studies so far published are of Lewis Glacier in Kenya (Hastenrath, 1984, 1989) and of two glaciers in the Cordillera Blanca, Peru (Ames, 1985; Kaser and others, 1990). These studies were conducted by collecting data on a yearly basis and were not coupled with systematic runoff measurements.

However, the coincidence at low latitudes between the wet season, favourable to accumulation, and the warm period, when ablation is maximum, makes it difficult to acquire knowledge of glacier mass balance from simple annual data. Furthermore, the precipitation distribution is fairly variable from year to year and the duration of the rainy season is yet more unpredictable. The glacier may be expected to react significantly to this variability.

Thus, if we want to understand the processes that control glacier mass balance in these regions, it is necessary to conduct measurements on a monthly basis and follow up the survey over a period of several years. With such an approach, it is possible to attain a greater understanding of the main factors that control the rapid glacier retreat presently occurring in this part of the Andes (Lliboutry and others, 1977; Ames, 1985; Jordan, 1991), as well as in other low-latitude mountains (Hastenrath and Kruss, 1992). Another question needing to be addressed is the consequence of an ENSO (El NiñoSouthern Oscillation) event for the glacier mass balance. According to the study at the Quelccaya Ice Cap, Peru (Thompson and others, 1984), ENSO events could affect mass balance by decreasing snow accumulation at high altitude in the Andes. Nevertheless, the marked reduction in precipitation during these episodes occurs during the warm season, so the effects on the mass balance could also be associated with a strong ablation (Francou, 1992).

Our investigation has concentrated on two glaciers in the Cordillera Real, Bolivia: Zongo Glacier and Chacaltaya Glacier. This paper presents the data collected on Zongo Glacier during the first two hydrological years of the study, from September 1991 to August 1993. It represents a first attempt to present a monthly pattern of glacier mass balance in the tropics and to analyse the effect of an ENSO event.

\section{AREA DESGRIPTION AND DATA-GATHERING METHODS}

The glacier is situated in the Huayna Potosí massif $(6088 \mathrm{~m})$, at $16^{\circ} \mathrm{S}$, in the Amazon basin. This valley-type glacier is $3 \mathrm{~km}$ long and has a surface area of $2.1 \mathrm{~km}^{2}$ (Fig. 1). The upper reaches are exposed to the south whereas the lower section faces east. The maximum and minimum elevations are 6000 and $4890 \mathrm{~m}$ a.s.l., respec- 


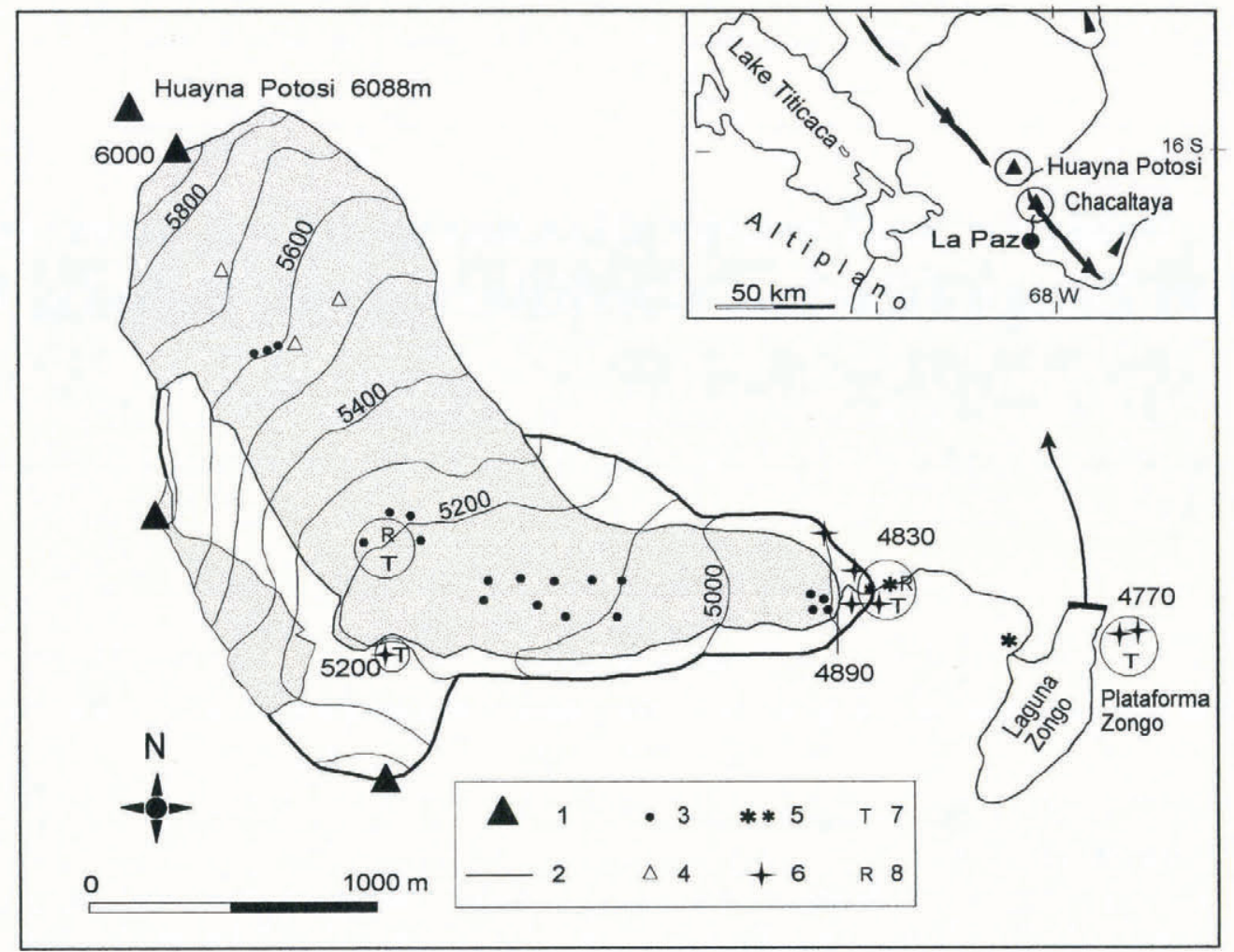

Fig. 1. Huayna Potosi and Zongo Glacier with the survey system in 1993. 1, Principal peaks; 2, Limits of basin; 3, Stakes; 4, Pits and crevasses; 5, Water-level recorder; 6, Rain-gauges; 7, Thermograph; 8, Pyranometer.

tively. The accumulation zone amounts to $60 \%$ of the total area under steady-state conditions (annual mass balance approaching zero), at an equilibrium-line altitude (ELA) of $5100 \mathrm{~m}$. Under similar conditions, average precipitation at the ELA totals $1.0 \mathrm{ma}^{-1}$ and the average temperature is $-2^{\circ} \mathrm{C}$. Thus, it can be deduced that this glacier is mainly temperate with a limited cold surface near the summit.

A 15 stake network was placed in the ablation zone in order to determine the mass balance and the surface velocity, augmented by a further three stakes and several pits in the accumulation zone from 5500 to $5800 \mathrm{~m}$ (Fig. 1). The 15 stakes in the ablation zone were surveyed every month and the surface density of the snow and ice was measured in order to obtain the amount of accumulation and ablation in water equivalent. The accumulation in the upper reaches of the glacier was recorded immediately before and after the wet season, in September and April. Annual net balance was evaluated between the beginning and end of the hydrological year, September-August. For the ice falls not surveyed by the stake network (the 5050-4950 and 5500-5300 m altitude ranges), net balance was estimated by linear interpolation. Mass balance was also computed independently by means of a hydrological method (Ribstein and others, in press), whereby we have the possibility of verifying the mass-balance values obtained by the glaciological method. In order for this to be done, a water-level recorder was set at $4830 \mathrm{~m}(150 \mathrm{~m}$ below the glacier terminus), providing continuous runoff measurements. Five storage rain-gauges, surveyed monthly, were placed near the glacier at 5200 and $4900-4850 \mathrm{~m}$. These raingauges, with a cross-section of $2000 \mathrm{~cm}^{2}$, have proved to be suitable for measuring snow precipitation and have shown an increase of $20 \%$ over the precipitation levels indicated by the lone classical $314 \mathrm{~cm}^{2}$ rain-gauge in place since 1970 on Plataforma Zongo $(4770 \mathrm{~m})$.

In order to obtain estimates of the parameters controlling glacier ablation, thermographs with radiation shields were placed at 5200, 4830 and $4770 \mathrm{~m}$. More recently, in 1993, pyranometers capable of measuring global radiation were sited at 5200 and $4830 \mathrm{~m}$, with a radiometer placed at $5200 \mathrm{~m}$ so as to record the net allwave radiation.

Every year since 1991, a topographic survey has been conducted in August on the 15 ablation stakes and on the terminus contour to give estimates of the surface velocity and of the terminus fluctuation. During the first year of the study, the measured glacier retreat was $10-20 \mathrm{~m}$, whereas during the second year the glacier terminus was stationary.

The easy accessibility of the glacier all the year round makes it possible to claim high levels of accuracy for data collected during the 2 years. But the progressive adjustment of the survey network during this time does not allow us to use all the collected data in this paper.

\section{MONTHLY NET BALANGE IN THE ABLATION ZONE, 1991-93}

The climates of 1991-92 and 1992-93 present very different patterns. The first year was marked by maturephase ENSO conditions (Kousky, 1993). Values of the south-oscillation index (the difference between the standardised sea-level pressure anomalies at Tahiti and 
Darwin) were strongly negative, with a minimum -2.2 standardised value for the 5 month running mean. This is the lowest monthly value since the 198283 episode, which has been described as a very strong event. Such a situation in the Pacific is associated with low precipitation levels in the central Andes. This observation was first pointed out in the Quelccaya Ice Cap by Thompson and others (1984), and analysed further by Francou and Pizarro (1985) and Tapley and Waylen (1990), using data collected from meteorological stations.

The second year was quite normal. Temperatures recorded over a period of $30 \mathrm{a}$ at the Chacaltaya station $(5230 \mathrm{~m}), 10 \mathrm{~km}$ south of Zongo Glacier, and precipitation collected over a 20 a period at Plataforma Zongo $(4770 \mathrm{~m})$ enable us to calibrate each month during both observed years (Fig. 2). Thus, a clear positive deviation of the maximum temperature could be observed from January to May during the first year, linked with a higher radiation input and a deficit of rainfall. During a normal hydrological year, 7 months have more than $50 \mathrm{~mm}$ of precipitation, whereas in 1991-92 only 4 exceeded this total.
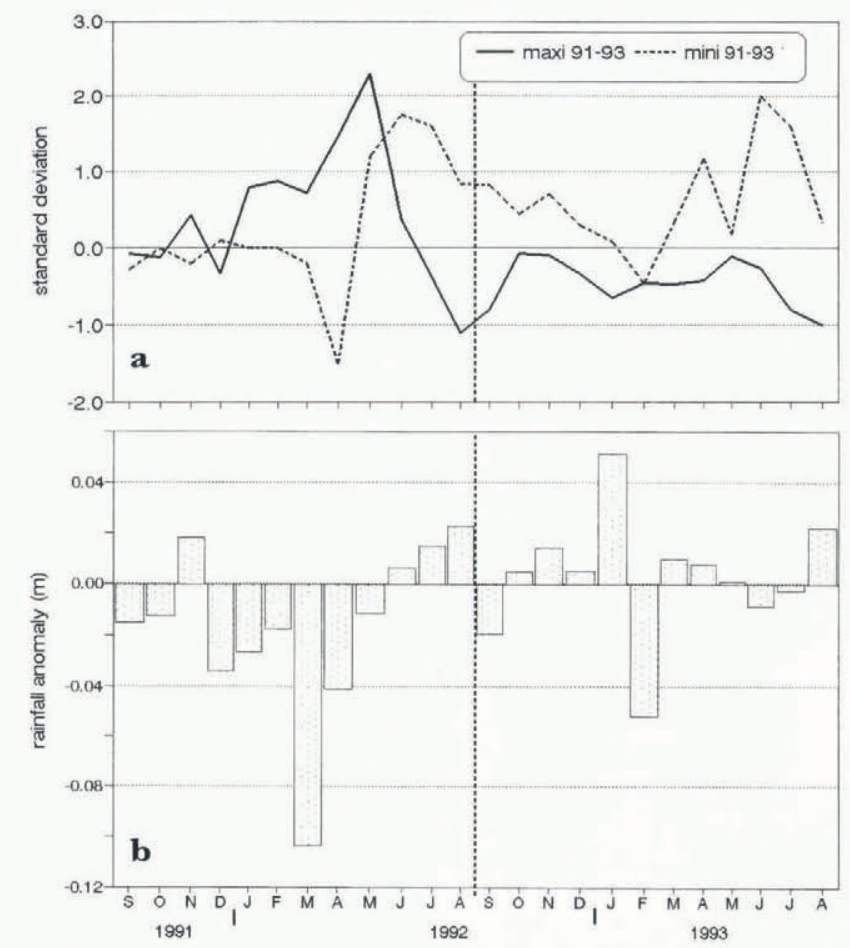

Fig. 2. Standard deviation of (a) maximum and minimum 1991-93 monthly temperatures from the 1953-93 mean at Chacaltaya $(5230 \mathrm{~m})$; (b) monthly $1991-93$ precipitation from the 197293 mean at Plataforma Zongo $(4770 \mathrm{~m})$.

As presented in Figure 3, the monthly evolution of glacier balance in the ablation zone is more complex than may be inferred from the simple wet season/dry season alternation typical of the tropics. During the ENSO event of 1991-92 a markedly negative net balance occurred in October-December and March-May, just before and after a short period of accumulation (January-February). During the average year 1992 93, negative mass balance was limited to the beginning of the hydrological year, with April and May showing limited ablation. The variation in the balance from $5200 \mathrm{~m}$ to the terminus for every month of the first year of the study is presented in Figure 4a. Immediately before and after the JanuaryMarch period the major part of the glacier experienced a strong ablation regime, even right up to high elevations. On the other hand, during a normal year such as 1992 93 (Fig. 4b), the monthly balance switched rapidly to a positive value. Whilst awaiting data over a longer period of time, we can already stress that October-December and March-May are decisive in the determination of the annual mass balance. In the central Andes, these are the months when variability of climate is at a maximum. However, it is obvious that the cold, dry months of June August do have a limited influence at year scale, since the mass balance during these months approaches zero.

\section{ANNUAL NET BALANCE AND WATER DISCHARGE}

For each year, the net balance $\beta_{\mathrm{n}}$ has been calculated by integrating the mass balance over the total surface area $S$, according to Equation (1).

$$
\beta_{\mathrm{n}}=\int_{S_{\mathrm{c}}} b_{\mathrm{n}} \mathrm{d} S+\int_{S_{\mathrm{a}}} b_{\mathrm{n}} \mathrm{d} S
$$

where $S_{\mathrm{c}}$ and $S_{\mathrm{a}}$ are the areas computed for the accumulation and ablation zones, respectively.

Over the two years, the specific net balance $\left(\beta_{\mathrm{n}}\right)$ per year was:

$$
\text { in 1991 } 92:-1.38 \mathrm{~m} \text { of water }
$$$$
\text { in 1992-93: }+0.02 \mathrm{~m} \text { of water. }
$$

The ELA was situated in 1991-92 at $5300 \mathrm{~m}$ and in 199293 at $5100-5150 \mathrm{~m}$ (Fig. 5). In the same figure, we note that: (1) the curves are more-or-less parallel from one year to the other, as already observed on many middlelatitude glaciers, first by Meier and Tangborn (1965) and Lliboutry (1974); (2) during the ENSO event of 1991-92 the amount of accumulation at high elevation is very low and this confirms the observations of Thompson and others (1984) in Quelccaya. In such a case, even a glacier which like Zongo Glacier extends over a great altitude range may be almost completely submitted to an ablation regime.

As indicated in Figure 6, the ENSO event 1991-92 was characterised by high runoff depths from October to December, with the December maximum $100 \mathrm{~mm}(33 \%)$ higher than during the following year. Furthermore, a second runoff peak occurred in March 1992, with runoff then remaining high in April and May. This confirms that a marked deficit in the precipitation late in the warm season, March-April 1992, allows a rapid melting of the snow cover accumulated in January-February. The water discharge at the outlet of the $3 \mathrm{~km}^{2}$ basin was $5.38 \times 10^{6} \mathrm{~m}^{3}$ in the first year and $3.24 \times 10^{6} \mathrm{~m}^{3}$ in the second. Considering the average precipitation $(P)$ collected in the rain-gauges, the total precipitation received by the glacier was $0.916 \mathrm{~m}$ in 1991-92 and $1.060 \mathrm{~m}$ in $1992-93$. We may assume that the area outside the glacier, $0.9 \mathrm{~km}^{2}$, has a runoff coefficient of 0.8 . This coefficient is quite important for a free glacier catchment 


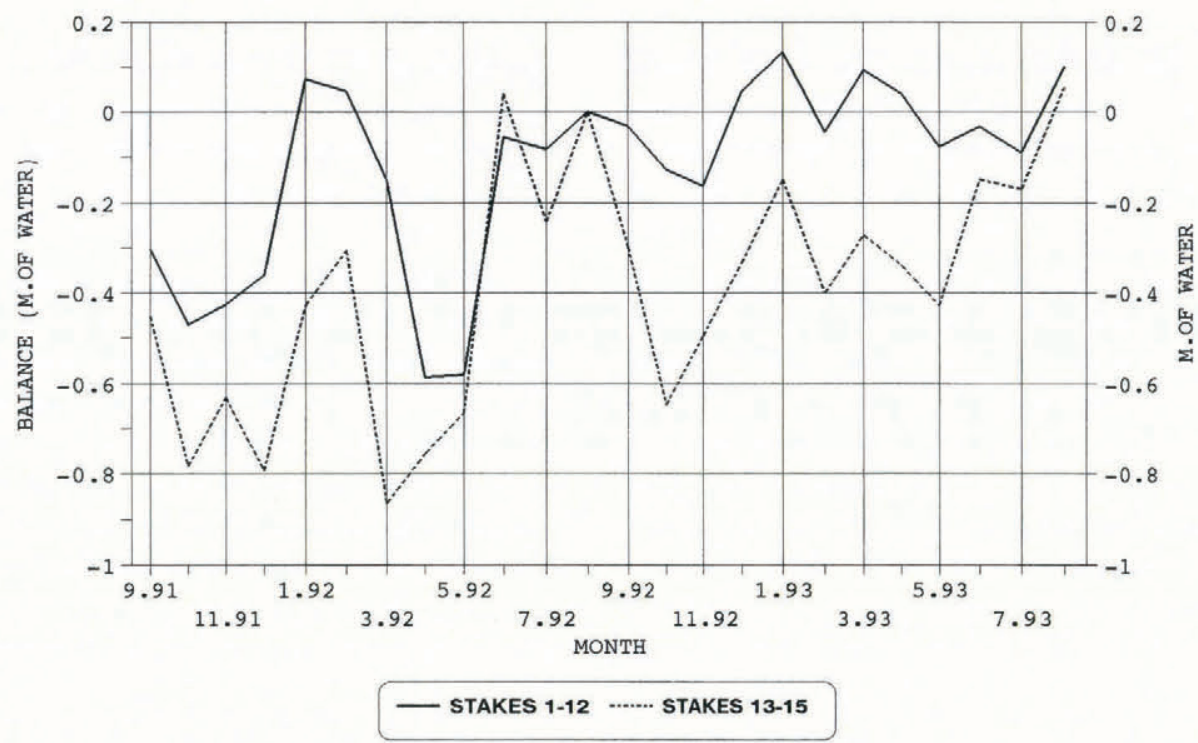

Fig. 3. Monthly balance from September 1991 to August 1993 in the ablation zone, calculated using two groups of stakes. Stakes 1-12 are situated near the ELA $(5200-5100 \mathrm{~m})$ and stakes 13-15 are near the glacier terminus $(4900 \mathrm{~m})$. The balance was estimated from a monthly stake reading and a density measurement of the snow/ice surface.
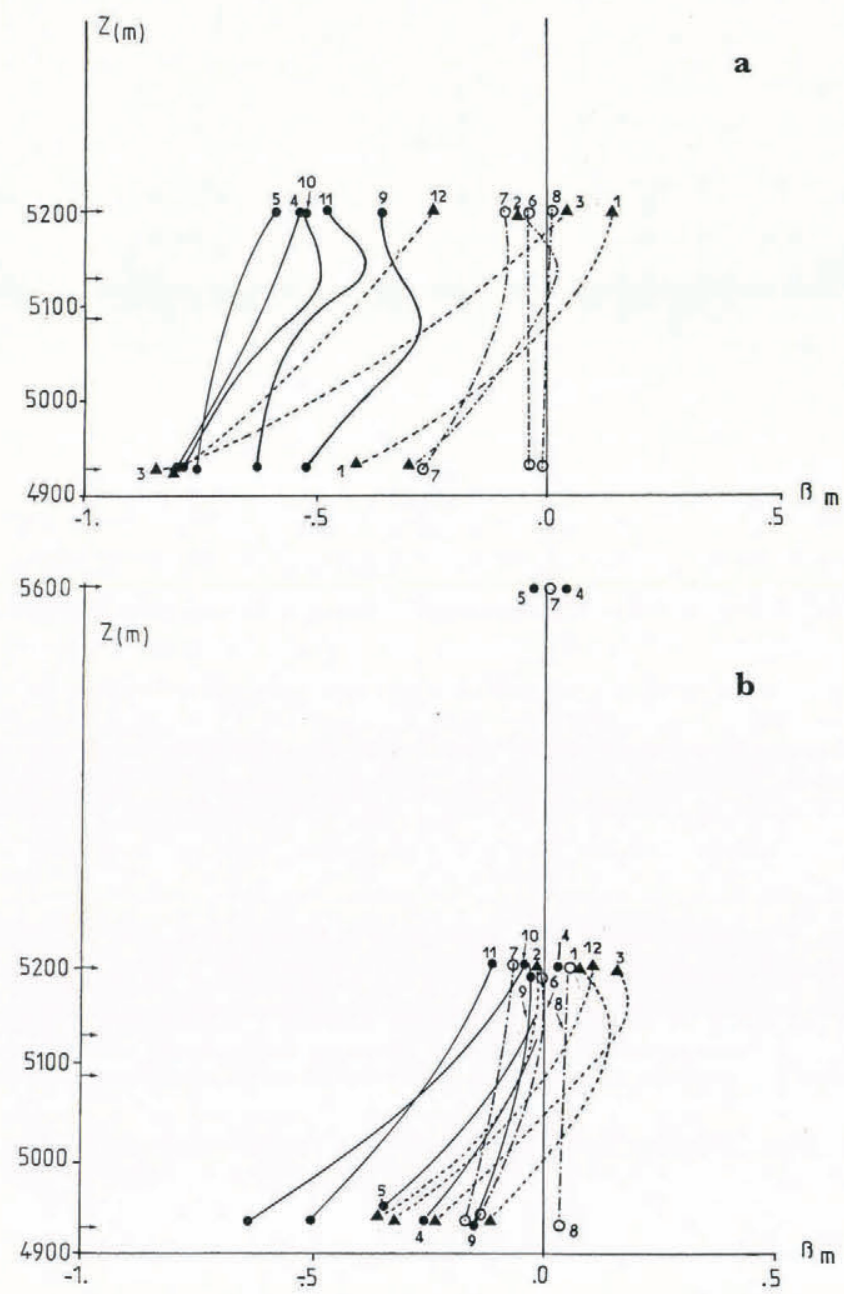

Fig. 4. Monthly net balance ( $\beta_{\mathrm{m}}$ in $m$ of water) as a function of altitude ( $Z$ ) during (a) 1991-92, and (b) 1992-93. Numbers 1-12 refer to the months. Solid line: September, October, November, April, May. Dashed line: June, July, August. Dotted line: December, January, February, March. in this Andean region (Bourges and others, 1992). Hence, the water discharge corresponding to this area was $0.66 \times 10^{6} \mathrm{~m}^{3}$ in $1991-92$ and $0.76 \times 10^{6} \mathrm{~m}^{3}$ in $1992-93$. Thus, the amount of melted snow and ice corresponding to a $2.1 \mathrm{~km}^{2}$ surface area is:

in 1991-92: $2.25 \mathrm{~m}$

in 1992-93: $1.18 \mathrm{~m}$

The specific net balance $\left(\beta_{\mathrm{n}}\right)$ and the precipitation $(P)$ being known, the total ablation $(A)$ is deduced from Equation (2):

$$
A=P-\beta_{\mathrm{n}} .
$$

In 1991-92: $2.30 \mathrm{~m}$ in 1992-93: $1.04 \mathrm{~m}$.

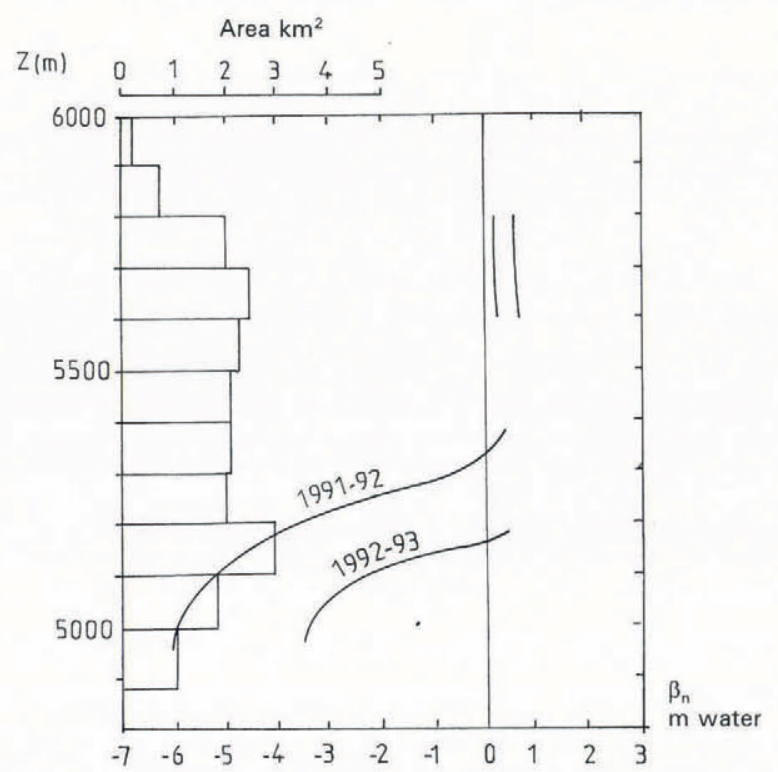

Fig. 5. Annual net balance ( $\beta_{\mathrm{n}}$ in $m$ of water) as a function of the altitude $Z$ during 1991-92 and 1992-93. It should be noted that the ELA was at $5300 \mathrm{~m}$ in 1991-92 and at $5100 \mathrm{~m}$ in 1992-93. 

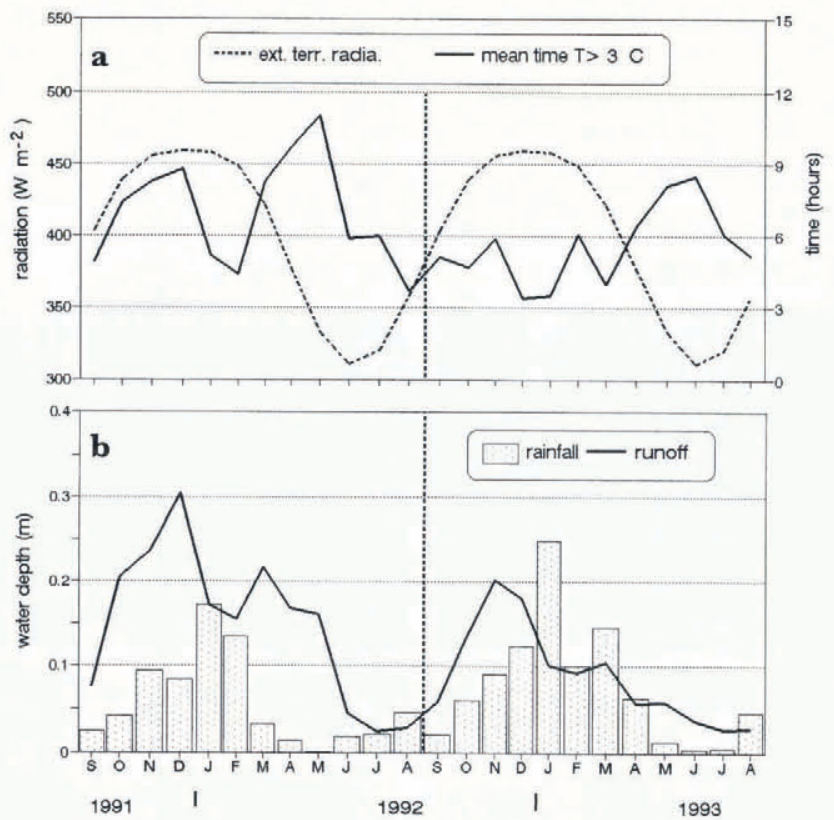

Fig. 6. (a) Extraterrestrial radiation and mean of hours per day with temperature above $3^{\circ} \mathrm{C}$, and $(b)$ rainfall and monthly runoff depth, on Zongo Glacier during the 2 years of the study.

Consequently, it should be noted that the glaciological and hydrological balances give similar results. The loss by sublimation seems to be very small, lower than $10 \%$ of the total ablation. Considering the data accuracy, the sublimation cannot be determined by means of the hydrological balance. This is consistent with the low values of sublimation obtained by Hastenrath (1978) at the summit of the Quelccaya Ice Cap.

\section{FACTORS CONTROLLING THE GLACIER BALANGE}

Whilst awaiting the opportunity to model the glacier ablation from recently installed temperature and radiation records, we can make a preliminary attempt to ascertain which variables are important in estimating the specific net-balance evolution in the ablation area of the glacier (i.e. between 5200 and $4890 \mathrm{~m}$ ).

A stepwise multiple linear regression was applied to a large number of possible independent variables. From amongst all of the independent variables, the best result obtained pinpointed the following three as being the most critical:

(1) the amount of radiation from the Sun arriving at the outer edge of the atmosphere, also called extra-terrestrial radiation: $H_{\mathrm{o}}$ in $\mathrm{W} \mathrm{m}^{2}$. This is constant at year scale, and obviously has a great influence at high altitudes at this low latitude. The monthly radiation values (Table 1; Fig. 6a) were calculated using the equations of Paltridge and Plate (1976);

(2) the average daily duration of air temperature greater than $3{ }^{\circ} \mathrm{C}$ at Plataforma Zongo $(4770 \mathrm{~m})$ : ${ }_{\mathrm{d}} T_{3}$ in $\mathrm{hd}^{-1}$ (Table 1; Fig. 6a). Given the lapse rate of $0.74^{\circ} \mathrm{C} 100 \mathrm{~m}^{-1}$ calculated between the two thermographs at 4770 and $5200 \mathrm{~m}$, this $3^{\circ} \mathrm{C}$ temperature is equivalent to a positive temperature over practically all of the ablation zone;

(3) the precipitation collected at $4770 \mathrm{~m}: P$ in $\mathrm{m}$ (Table 1; Fig. 6b).

With the specific net balance estimated in the ablation zone of the glacier ( $\beta_{\mathrm{n}_{\mathrm{a}}}$ in $\mathrm{m}$ of water (Table 1; Fig. $\left.6 \mathrm{~b}\right)$ ), the linear regression using the monthly data is:

$$
\begin{gathered}
\beta_{\mathrm{n}_{\mathrm{a}}}=-0.07565\left({ }_{\mathrm{d}} T_{3}-0.00329\left(H_{\mathrm{o}}\right)+1.74 P+1.413\right. \\
\text { with } r^{2}=0.84, n=24,
\end{gathered}
$$

where $r^{2}$ is the correlation coefficient and $n$ is the number of data.

It may be noted that ${ }_{\mathrm{d}} T_{3}$ is the best correlated variable $(r=-0.72)$.

With the runoff depth $Q$ (in $\mathrm{m}$ ) as the dependent variable (Table 1; Fig. 6b), the best regression was obtained using the $H_{0}$ and ${ }_{\mathrm{d}} T_{3}$ variables:

$$
\begin{array}{r}
Q=0.00128\left(H_{\mathrm{o}}\right)+0.02358\left({ }_{\mathrm{d}} T_{3}\right)-0.538 \\
\text { with } r^{2}=0.86, n=24 .
\end{array}
$$

This time, the variable with the best correlation coefficient is $H_{\mathrm{o}}: r=0.80$.

These results suggest the following three comments:

(1) Temperature and radiation closely control the ablation in the lower part of the glacier.

(2) The greatest amount of solar radiation, leading to the melting of the greatest quantity of snow and ice, occurs near the time of the summer solstice. Therefore, we can begin to understand why a deficit in precipitation, and hence less frequent cloud-cover during this period, leads to the most significant melt. According to the observations of Ribstein and others (in press), the highest discharge recorded at the limnimetric station occurred after a $10 \mathrm{~d}$ dry period during the warm season (October-March). It is clear that dry periods during the warm season are more frequent during ENSO events. It should be noted that the ablation produced during the dry season (April-September) with low radiation is not very significant at year scale.

(3) Precipitation appears to be poorly correlated with glacier ablation and runoff, since in general the precipitation is of a solid form. Accumulated snow and hail have a melt time varying according to the climatic conditions. It might be possible at a later stage to determine these conditions.

\section{CONCLUSIONS}

For the first time, the collection of monthly data on an inter-tropical glacier allows us to highlight the most important factors that control mass balance at low latitudes. These factors are the duration of the wet season within the warm period, and the temperature 


\begin{tabular}{|c|c|c|c|c|c|}
\hline \multirow[t]{2}{*}{ Month } & \multirow{2}{*}{$\begin{array}{c}\text { Balance }^{1} \\
\mathrm{~m}\end{array}$} & \multirow{2}{*}{$\begin{array}{c}\text { Runoff }^{2} \\
\mathrm{~m}\end{array}$} & \multirow{2}{*}{$\begin{array}{l}\text { Precipit- } \\
\text { ation }^{3} \\
\mathrm{~m}\end{array}$} & \multirow{2}{*}{$\begin{array}{c}{ }_{d} \mathrm{~T}_{3}{ }^{4} \\
\mathrm{~h}\end{array}$} & \multirow{2}{*}{$\begin{array}{c}H_{o}^{5} \\
\mathrm{~W} \mathrm{~m}{ }^{-2}\end{array}$} \\
\hline & & & & & \\
\hline September 1991 & -0.378 & 0.076 & 0.025 & 4.9 & 403.8 \\
\hline October 1991 & -0.627 & 0.205 & 0.042 & 7.4 & 439.2 \\
\hline November 1991 & -0.528 & 0.237 & 0.090 & 8.3 & 455.9 \\
\hline December 1991 & -0.576 & 0.305 & 0.081 & 8.8 & 459.8 \\
\hline January 1992 & -0.178 & 0.171 & 0.164 & 5.2 & 458.3 \\
\hline February 1992 & -0.131 & 0.154 & 0.129 & 4.4 & 448.5 \\
\hline March 1992 & -0.507 & 0.217 & 0.032 & 8.3 & 421.5 \\
\hline April 1992 & -0.671 & 0.168 & 0.015 & 9.7 & 377.5 \\
\hline May 1992 & -0.624 & 0.160 & 0.001 & 11.0 & 334.0 \\
\hline June 1992 & -0.008 & 0.045 & 0.018 & 5.9 & 311.6 \\
\hline July 1992 & -0.162 & 0.025 & 0.021 & 6.0 & 320.9 \\
\hline August 1992 & 0.000 & 0.029 & 0.045 & 3.7 & 357.9 \\
\hline September 1992 & -0.165 & 0.059 & 0.021 & 5.1 & 403.8 \\
\hline October 1992 & -0.388 & 0.136 & 0.060 & 4.7 & 439.2 \\
\hline November 1992 & -0.329 & 0.202 & 0.090 & 5.9 & 455.9 \\
\hline December 1992 & -0.144 & 0.179 & 0.123 & 3.4 & 459.8 \\
\hline January 1993 & -0.009 & 0.102 & 0.249 & 3.5 & 458.3 \\
\hline February 1993 & -0.222 & 0.092 & 0.100 & 6.1 & 448.5 \\
\hline March 1993 & -0.089 & 0.104 & 0.146 & 4.0 & 421.5 \\
\hline April 1993 & -0.149 & 0.058 & 0.063 & 6.4 & 377.5 \\
\hline May 1993 & -0.252 & 0.058 & 0.013 & 8.1 & 334.0 \\
\hline June 1993 & -0.090 & 0.036 & 0.003 & 8.5 & 311.6 \\
\hline July 1993 & -0.130 & 0.026 & 0.004 & 6.1 & 320.9 \\
\hline August 1993 & +0.077 & 0.028 & 0.046 & 5.2 & 357.9 \\
\hline
\end{tabular}

\footnotetext{
${ }^{1}$ Mean net specific glacier balance in the ablation zone $5200-4900 \mathrm{~m}$.

${ }^{2}$ Runoff depth related to the basin area of $3.0 \mathrm{~km}^{2}$ recorded at the limnimetric station.

${ }^{3}$ Precipitation at Plataforma Zongo, $4770 \mathrm{~m}$.

${ }^{4}$ Daily mean of hours with temperature $>3{ }^{\circ} \mathrm{C}$ at Plataforma Zongo, $4770 \mathrm{~m}$.

${ }^{5}$ Extraterrestrial radiation.
}

level during the sensitive period which precedes and follows January-February, the height of the rainy season.

Hence, it can be noted that mass-balance determination is more complex for tropical glaciers than for their cousins at middle latitudes, for which only the three summer months appear to be critical. Since the climate in this part of the Andes is so variable, a longer-term study will be necessary to better understand this subject.

The second conclusion reached concerns the effect of the ENSO events. In comparison with the "normal" 1992-93 hydrological year, 1991-92 (an ENSO event) was characterised by: (1) a markedly negative net balance, with a water depletion equivalent to twice the amount of the precipitation accumulated; (2) an increase in the elevation of the ELA by $200 \mathrm{~m}$; (3) a reduction of the AAR (accumulation-area ratio) from $86 \%$ to $58 \%$; (4) a very low accumulation rate at high altitude.

The above effects are a consequence of a marked increase of ablation due to a rise in the maximum temperature during the summer period, associated with increased radiation input, and also linked to the deficit in accumulation arising from a foreshortened season of 2 instead of the normal 4 months.

Thus the conclusions reached by Thompson and others (1984) from the study of the Quelccaya Ice Cap concerning a decrease in the accumulation during ENSO events are confirmed. Furthermore, we can add that the ENSO effect modifies not only the accumulation term in the mass-balance equation, but also the ablation term, particularly in the present case study. The observations made during the 1991-92 ENSO event are confirmed by our analysis of water-level records from the Zongo Glacier outlet over a 20 a period (Ribstein and others, in press). The records reveal that the highest levels of runoff over this period were obtained during the three previous ENSO events (1976-77, 1982-83 and 1986-87), with a particularly high peak during the strong 1982-83 event.

The continuation of the present study over a period of several years would clearly be beneficial in furthering our understanding as to why tropical glaciers are currently experiencing such rapid retreat. Of further use would be a long-term study of mass-balance data from various other Andean glaciers. 
It is already widely acknowledged that global atmospheric warming is a cause of glacier retreat. However, our study suggests that another important factor is the occurrence of short periods of warm, dry weather during the rainy season, a combination that is frequently linked to ENSO events.

\section{ACKNOWLEDGEMENTS}

The glaciological programme was initially supported by Dr M. Servant (L'Institut Français de Recherche Scientifique pour le Développement en Coopération). For the field measurements, the efforts of F. Quispe and the technicians of the Bolivian Power Company (COBEE) are much appreciated. The comments of Dr L. Reynaud, Dr D. MacAyeal and an anonymous referee are also gratefully acknowledged.

\section{REFERENCES}

Ames, A. 1985. Estudio de mediciones glaciológicas efectuadas en la Cordillera Blanca por Electroperú S.A.: variaciones y balance de masas de los glaciares y su contribución en el caudal de las cuencas. Grenoble, Centre National de la Recherche Scientifique. Laboratoire de Glaciologie et de Géophysique de l'Environnement. (Publication 457.)

Bourges, J., P. Ribstein, R. Hoorelbeke, C. Dietze and J. Cortez. 1992. Precipitaciones y escurrimiento de una pequeña cuenca en zona de montaña: el rio Achumani (La Paz-Bolivia). In Ricaldi, V., C. Flores and L. Anaya, eds. Los Recursos Hidricos en Bolivia y su Dimension Ambiental. International Symposium. Cochabamba (Bolivia), $303-312$. Geoscience Series 20, Association of Geoscientists for International Development.)

Francou, B. 1992. Medidas de balance efectuadas sobre un glaciar en la Cordillera Central del Peru durante "El Niño" de 1983. In Ortlieb, L. and J. Macharé, eds. Paleo-E.NSO Records. International Symposium.
Extended abstracts. Lima, L'Institut Français de Recherche Scientifique pour le Développement en Coopération Consejo Nacional de Ciencia y Tecnología, 107-110.

Francou, B. and L. Pizzaro. 1985. El Niño y la sequía en los Altos Andes centrales (Perú y Bolivia). Bull. Instituto Francés de Estudios Andinos (Lima), 14 (1-2), 1-18.

Hastenrath, S. 1978. Heat-budget measurements on the Quelccaya ice cap, Peruvian Andes. F. Glaciol., 20 (82), 85-97.

Hastenrath, S. 1984. The glaciers of equatorial East Africa. Dordrecht, etc., D. Reidel Publishing Co.

Hastenrath, S. 1989. Ice flow and mass change of Lewis Glacier, Mount Kenya, East Africa: observations 1974 86, modelling, and prediction to the year 2000 A.D. f. Glaciol., 35 (121), 325332.

Hastenrath, S. and P.D. Kruss. 1992. The dramatic retreat of Mount Kenya's glaciers between 1963 and 1987: greenhouse forcing. Ann. Glaciol., 16, 127-133.

Jordan, E. 1991. Die Gletscher der bolivianischen Anden. Stuttgart, Franz Steiner Verlag.

Kaser, G., A. Ames and M. Zamora. 1990. Glacier fluctuations and climate in the Cordillera Blanca, Peru. Ann. Glaciol., 14, 136-140.

Kousky, V.E. 1993. The global climate of December 1991-February 1992: mature phase warm (ENSO) episode conditions develop. $f$. Climate, 6 8), 1639-1655.

Lliboutry, L. 1974. Multivariate statistical analysis of glacier annual balances. f. Glaciol., $13(69), 371-392$.

Lliboutry, L., B. Morales Arnao and B. Schneider. 1977. Glaciological problems set by the control of dangerous lakes in Cordillera Blanca, Peru. III. Study of moraines and mass balances at Safuna. J. Glaciol., $18(79), 275-290$.

Meier, M. F. and M. V. Tangborn 1965. Net budget and flow of South Cascade Glacier, Washington. J. Glaciol., 5(41), 547-566.

Paltridge, G. W. and C. M. R. Platt. 1976. Radiative processes in meteorology and climatology. Amsterdam, Elsevier.

Ribstein, P., E. Tiriau, B. Francou and R. Saravia. In press. Tropical climate and glacier hydrology. A case study in Bolivia. 7. Hydrol.

Tapley, T.D. and P.R. Waylen. 1990. Spatial variability of annual precipitation and ENSO events in western Peru. Hydrological Sciences Journal, $35(4), 429446$.

Thompson, L. G., E. Mosley-Thompson and B. Morales Arnao. 1984, El Niño-Southern Oscillation events recorded in the stratigraphy of the tropical Quelccaya ice cap, Peru. Science, 226(4670), $50-53$. 